\title{
Keeping it Clean: Your Countertop ${ }^{\mathbf{1}}$
}

Mary N. Harrison ${ }^{2}$

\section{Supplies Needed}

- Soft cloth.

- Dishwashing detergent.

- Baking soda or a few drops of chlorine bleach.

\section{Daily Care}

- Clean countertops daily with a soft cloth that has been dipped in hot soapy water, then rinse and dry. (Food particles attract bacteria and roaches.)

- If your countertop is not completely smooth, you may need to use a brush with hot soapy water to clean the indentations.

- Use a few drops of liquid chlorine bleach or baking soda to remove stains from kitchen counters.

- DO NOT use abrasive cleaners. They scratch the surface and make it harder to clean.

\section{Helpful Hints}

- Clean spills and crumbs as you prepare food and after meals. Many foods such as coffee, tea, blueberries, and certain sauces stain quickly. Immediately wipe up spills that stain.

- Protect the countertop. Use a cutting board when using a knife or other cutting tool. Scratch marks make the counter less attractive as well as provide areas for germs and dirt to collect. This will attract roaches.

- Protect the countertop when using an appliance that may get very hot on the bottom - extreme heat over an extended period will cause most of the countertop materials to buckle.

- Occasionally wipe the cabinet doors and drawers with a soft soapy cloth, especially around handles when fingerprints tend to get it dirty. Rinse with clear water and dry.

1. This document is FCS5232-06, one of a series of the Family Youth and Community Sciences Department, Florida Cooperative Extension Service, Institute of Food and Agricultural Sciences, University of Florida. Original publication date June 2002. Revised December 2005. Visit the EDIS Web Site at http://edis.ifas.ufl.edu.

2. Mary N. Harrison, professor, Department of Family, Youth and Community Sciences, Cooperative Extension Service, Institute of Food and Agricultural Sciences, University of Florida, Gainesville, 32611.

The Institute of Food and Agricultural Sciences (IFAS) is an Equal Opportunity Institution authorized to provide research, educational information and other services only to individuals and institutions that function with non-discrimination with respect to race, creed, color, religion, age, disability, sex, sexual orientation, marital status, national origin, political opinions or affiliations. U.S. Department of Agriculture, Cooperative Extension Service, University of Florida, IFAS, Florida A. \& M. University Cooperative Extension Program, and Boards of County Commissioners Cooperating. Larry Arrington, Dean 